\title{
Evaluation of Corrosion for Magnetic Recording Media
}

\author{
Akiyo Mizutani, Keiji Watanabe*, Toyoo Miyajima*, Mineharu Tsukada*, \\ Masanori Fujinami**, and Koichi Oguma** \\ Fujitsu Limited, 1-1, Kamikodanaka 4-chome, Nakahara-ku, Kawasaki-city, Kanagawa 211-8588, Japan \\ *Fujitsu Laboratories Limited, 10-1, Morinosato-Wakamiya, Atsugi-city, Kanagawa 243-0197, Japan \\ ${ }^{* *}$ Chiba University, 1-33 Yayoi-cho, Inage-ku, Chiba, 263-8522, Japan
}

\begin{abstract}
The corrosion mechanisms of magnetic recording media in a high humidity environment were investigated by scanning electron microscopy (SEM), transmission electron microscopy (TEM) and a metal elution test, where drops of nitric acid on the media surface were analyzed by inductively-coupled plasma mass spectrometry (ICP-MS) measurement (droplet-method). By observing SEM images, the corrosion on the media surface was found to have accelerated with longer exposure to the high humidity environment. Moreover, the cross-sectional TEM images proved that the lower $\mathrm{NiP}$ layer was invaded by moisture from the dented part of the magnetic layer due to its texture. In addition, the droplet-method analysis revealed that $\mathrm{Co}$ and $\mathrm{Cr}$ in the magnetic layer and $\mathrm{Ni}$ in the plated NiP layer were found to have eluted through the diamond-like carbon (DLC) film by drops due to nitric acid. The relation between the elution behavior of the elements and the corrosion process was clarified by adjusting the time the media surface was in contact with the nitric acid droplets. Based on these results, a model mechanism for corrosion behavior due to the moisture is proposed.
\end{abstract}

Keywords: Magnetic recording media, DLC, corrosion, ICP-MS

\section{磁気ディスクにおける腐食性評価}

\author{
水谷晶代，渡部慶二*，宮島豊生*，塚田峰春*，藤浪眞紀**，小熊幸一** \\ 富士通（株），神奈川県川崎市中原区上小田中4-1-1（テ 211-8588） \\ *（株）富士通研究所，神奈川県厚木市森の里若宮 10-1（广243-0197） \\ **葉大学 自然科学研究科, 千葉県千葉市稲毛区弥生町 1-33（戸 263-8522）
}

\section{1. はじめに}

ハードディスク装置（Hard Disk Drive, 以下 HDD と略 す）は，高速で読み書きが可能なことや記録密度の高 さから, コンピュータばかりではなく多様な方面に使用さ れるようになってきた. そのため, いろいろな環境下に置 かれることが想定され, 従来の性能に加えて耐環境性が 問われるようになってきた. 以前より磁性膜における耐蝕 性の向上に関しては, 評価方法 1),2) や防食 ${ }^{3), 4), 5), 6) に つ ~}$ いて多数の報告がある. その結果, 磁性層自身の耐蝕 性や保護膜の性能が向上し, 現在の信頼性の高い製品 へ発展している.

一方で, 磁気記録密度の向上はここ 5 年程で約 10 倍といった勢いで進んでおり, 今後もさらなる高密度化が 見込まれる. 記録密度を向上させるためには, 読み書き を行なうへッドと記録を保持する磁気ディスク(以下, ディ スクと略す)の磁性層との間を限りなく接近させることが必 須となる. そのため, ヘッドと磁性膜の間にある, 各膜厚
や浮上量の低減が HDD の世代ごとに実施され, 現在で は, 潤滑剤膜厚は $1 \mathrm{~nm}$, Diamond Like Carbon (DLC)膜 厚は $4 \mathrm{~nm}$, 浮上量は $10 \mathrm{~nm}$ 程度の領域に突入してきて いる。ところが, 保護膜である DLC 膜の薄膜化は, 被覆 性の低下による高湿度環境下における磁性層からの腐 食発生が懸念される.この現象について Novotnyらは, 高 湿度環境下において, DLC膜の被覆性不良箇所から表 面吸着水との電気化学反応により磁性層の腐食が起こ り, ディスク表面に析出物が発生すると報告 7)している. わずか数 $\mathrm{nm}$ の浮上の隙間にこのような析出物が存在し た場合, ヘッドとディスクが接触し, HDD の故障に慗がる 危険性が非常に高くなる. そのため, DLC 膜の薄膜化 の実現には, 的確な被覆性評価技術の開発と腐食メカ ニズムの解明が重要となる. 今まで磁気ディスクの腐食 に関しては, 腐食部分の Scanning Electron Microscope (SEM)観察 8),9)や, X-ray Photoemission Spectroscopy (XPS), Time-of-Flight Secondary Ion Mass Spectroscopy (TOF- 
SIMS)等で物性を同定した報告 7),10) 11) があり, 耐腐食 性の評価に関しては電気化学的手法による方法 1),2)が 報告されているが，いずれも腐食後の状態観察からメカ ニズムを推測することが主であり, 腐食の過程を直接説 明する内容ではなかった。

そこで本研究では, ディスクの腐食過程を明らかにす るために, まず高湿度環境における腐食部の経時的な 変化を表面及び断面から観察した. さらにディスク表面 に溶出してくる各元素を定量的に評価できる, 高周波誘 導結合プラズマ質量分析計（ICP-MS）を使用した溶出 試験方法(Drop 法) 12),13)を適用し検討を行った。 ICP -MSは, 溶出元素を $1 \mathrm{E} 9$ atoms $/ \mathrm{cm}^{2}$ の極微量オーダ 一で測定することが可能であるため, 腐食の微量な状態 変化を定量的にとらえることができる.これらの結果より, 高湿度環境におけるディスクの腐食モデルを構築したの で報告する。

\section{2. 実験}

\section{1 試料ディスクの構造}

試料としたディスクの構造を Fig.1に示す. 直径 3.5 イン チの $\mathrm{Al}$ 製円盤基板の上にメッキ成膜法による $\mathrm{NiP}$ 膜が 約 $20 \mu \mathrm{m}$ あり, その上に DC スパッタ成膜法による $\mathrm{Cr}$ 系合 金 (Cr30 at\%)の下地層が $10 \mathrm{~nm}$ と $\mathrm{CoCr}$ 系合金 $(\mathrm{Co}$ : $\mathrm{Cr}=3: 1 \mathrm{at} \%)$ (磁性層が $20 \mathrm{~nm}$ があり, その上に保護膜の DLC膜となり, 最表層は潤滑剂が約 $1 \mathrm{~nm}$ の構造となって いる. 保護膜の DLC は Chemical Vapor Deposition (CVD) 法における成膜条件により $2,4.5,7,10,15,20 \mathrm{~nm} の 6$ 種 類の膜厚を成膜し, 各試料による被覆性を評価した.

\section{2 水蒸気による加湿方法及び腐食部の観察}

ディスクの加湿方法は, 微粒子等の污染による腐食と の混同を避けるため, クラス100のクリーン環境下で, 石 英製チャンバーの中に治具で縦置きにしたディスクと電 気抵抗が $18 \mathrm{M} \Omega \cdot \mathrm{cm}$ 以上の超純水を入れたシャーレー を置き, チャンバーごと恒温槽に入れる構成にした. 加湿 条件は, 温度を $70^{\circ} \mathrm{C}$ 一定とし, 飽和水蒸気圧の環境下

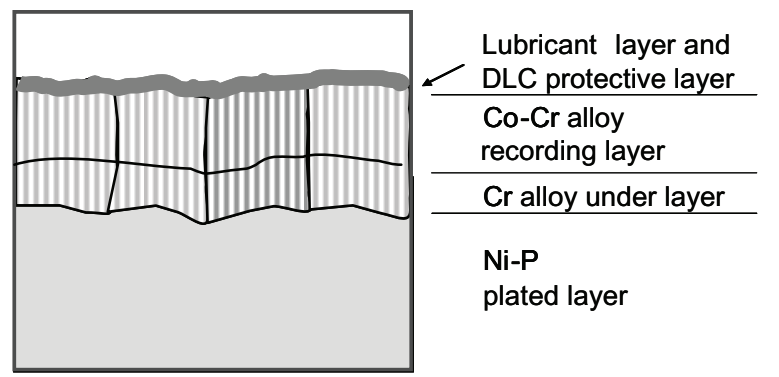

Fig. 1 Cross-sectional TEM image of magnetic recording media.
でディスクの放置時間を $1,5,100$ 時間とした.この試料 を用い, 表面を金属顕微鏡及び SEMで, NiP層から表層 部分の断面を Transmission Electron Microscope (TEM)で 観察した.

\section{3 溶出試験方法 (Drop 法)}

ディスクは表面が水平になるように置き, その上にマイ クロピペットで溶出液 $3 \%$ 硝酸を滴下する. 一定時間放置 後, 各液滴をピペットでポリプロピレン製のスピッチ管に 回収し, 液中の $\mathrm{Co}, \mathrm{Cr}$ 及び $\mathrm{Ni}$ 量を ICP-MSで測定する. ICP-MSの試料液導入部には, 流量 $100 \mu \mathrm{l} / \mathrm{min}$ の微少量 試料導入システム (Micro Flow Nebulizer: MFN) を使用 した. 本実験では, 溶出液量は $0.5 \mathrm{ml}$ (液滴直径: $7 \mathrm{~mm}$ ) とし, 直径 3.5 インチのディスク表面に 8 点形成した.

次に, 本実験における溶出時間は以下のように設定し た. DLC 膜厚 2, 4.5, $7 \mathrm{~nm}$ の場合は比較的薄い膜となり 速い溶出が考えられるため, 短い溶出時間を設定し, 20 分, 40 分, 1 時間, 2 時間の 4 条件で各 2 点ずつの面 内合計 8 点とした。一方, DLC膜厚 $10,15,20 \mathrm{~nm}$ の場合 は溶出量が少量であると考え， $1,2,3,4$ 時間と長く設定 した.こちらも同様に溶出箇所はディスク面内の 8 点の液 滴のうち 2 点を同じ溶出時間とした。ディスクは 3 枚使用 し, 各条件については合計 6 点の測定とした。

\section{3. 結果と考察}

\section{1 水蒸気暴露後のディスク表面の観察}

Fig. 2 に, 水蒸気雰囲気中に 100 時間放置したディス クの金属顕微鏡による暗視野像を示す. (a)では, DLC 膜厚 $2 \mathrm{~nm}$ において, 白色の輝点で観察される腐食痕が 同心円上にスジ状に出ている様子が確認できる.これは, ディスクの製造工程において平均粗さ $1 \mathrm{~nm}$ 以下の機械 的な傷 (テクスチャー) を故意につけるが, テクスチャーに よってできた凹の部分は被覆性が劣化し, それに沿って 腐食が起こると推測される.一方, (b)より, 膜厚 $4.5 \mathrm{~nm}$ の 試料では腐食痕の数は減少し, 被覆性が向上しているこ とがわかる.さらに, $4.5 \mathrm{~nm}$ 以上の膜厚の試料は全て(b)

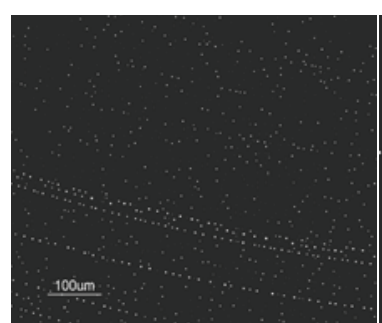

(a) DLC thickness : $2 \mathrm{~nm}$

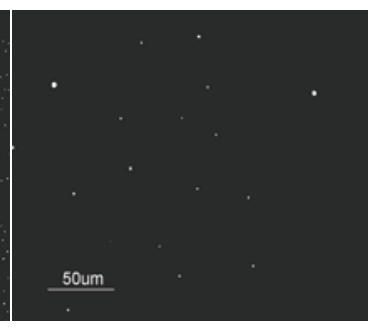

(b) DLC thickness : $4.5 \mathrm{~nm}$
Fig. 2 Optical microscopic dark field images of magnetic recording media exposed to high humidity. (a) $2 \mathrm{~nm}$ and (b) $4.5 \mathrm{~nm}$ DLC films. 
の写真と同様の観察結果となった. これより, DLC 膜厚 $4.5 \mathrm{~nm}$ 以上では, 被覆性が保持されていることがわかる. 金属顕微鏡による結果より, DLC 膜厚 $4.5 \mathrm{~nm}$ の試料に おいて腐食と防食作用の両方が観察できたため, この試 料の腐食部分について SEM 観察を行った.

Fig. 3 に, DLC膜厚 $4.5 \mathrm{~nm}$ の媒体表面に発生した腐食 痕の経時的な形状変化を SEM 観察した結果を示す. 5 時間暴露では, 直径約 $0.5 \mu \mathrm{m}$ の円形腐食痕が黒色 に観察され点在していた. 100 時間曝露では, 5 時間 暴露と比較してディスク上腐食部の個数はほぼ同数であ ったが, 個々の大きさが $1 \mu \mathrm{m}$ 以上に成長し, 表面の凹凸 が激しくなっていることがわかった。

\section{2 ディスクの断面観察}

Fig. 4 にDLC 膜厚 $4.5 \mathrm{~nm}$ のディスクの断面 TEM 観 察結果を示す. (a)の 1 時間暴露の試料において, NiP 層と磁性層の間に腐食部分 (写真白色部) が確認でき た.（b)の 100 時間の試料では NiP 層が大きく腐食され, 空洞化しているが, 磁性層の薄膜がその間に残存してい ることが確認できた.この様子から,この試料構造におけ る腐食は, NiP 層における浸食が支配的であることがう かがえる. ディスク表面にある析出物は元素分析より, $\mathrm{Ni}$, $\mathrm{P}$ 及び $\mathrm{O}$ が主成分であった。

1 時間暴露試料における断面 TEM 観察において, Fig. 5(a)は広い視野であり，(b)および(c)は腐食が確認 できた部分について拡大したものである.これらの断面写 真から, 磁性層や DLC 膜は, テクスチャーの傷の影響を 受けて $10 \sim 20 \mathrm{~nm}$ 間隔の微小な凹凸がある膜であるこ とがわかる. (a)の写真より, 腐食が開始していると考えら れる痕が観察されたのは, 磁性層の凹凸の中でもやや 深く落ち込んでいる部分であることがわかった. 金属顕微 鏡観察において, DLC 膜が $2 \mathrm{~nm}$ の試料においては, テクスチャーの傷跡に沿った腐食痕が観察されていたが, その結果を裹付けるものである. (b)及び(c)では, さらに 磁性層の結晶性に注目してみると, 結晶粒界に沿って 溶出が開始しているということが確認された。これは, 磁 性層の腐食の場合, 粒界で腐食が進行しやすいことを 意味していると考える.
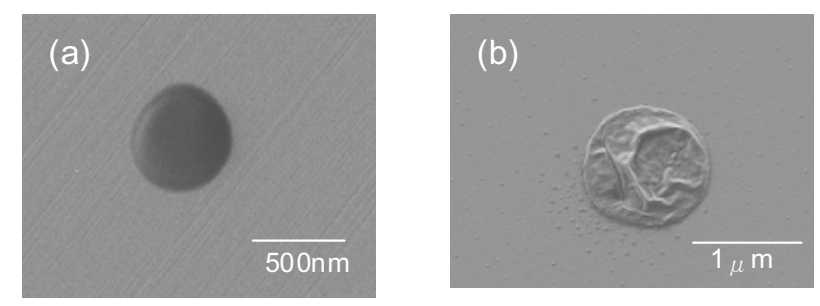

Fig. 3 Plane-view SEM images of magnetic recording media exposed to high humidity. (a) $5 \mathrm{hr}$ and (b) $100 \mathrm{hr}$.
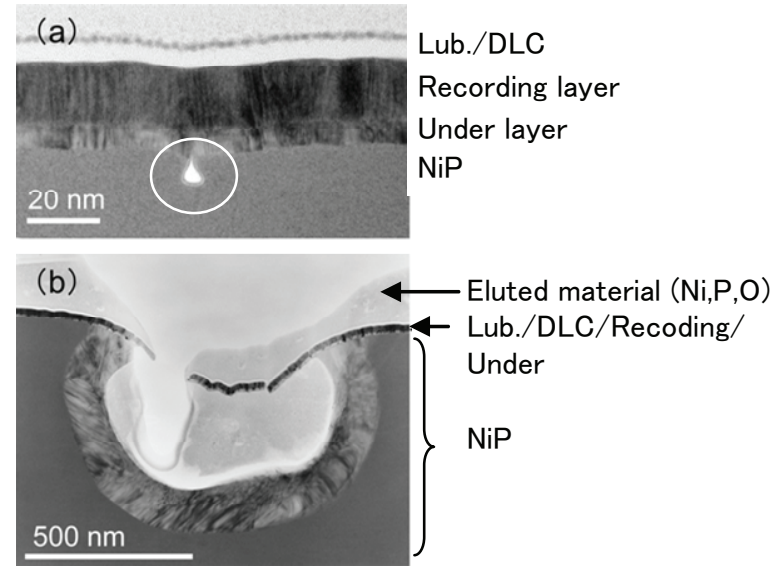

Fig. 4 Cross-sectional TEM images of surface of magnetic recording media exposed to high humidity. (a) $1 \mathrm{hr}$ and (b) $100 \mathrm{hr}$.

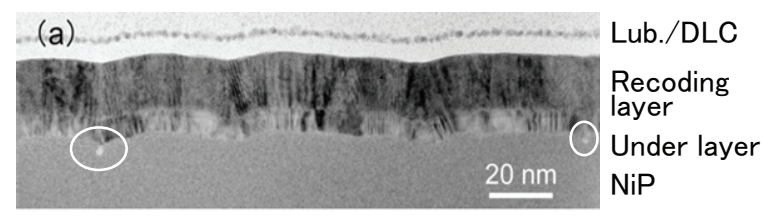

(b)

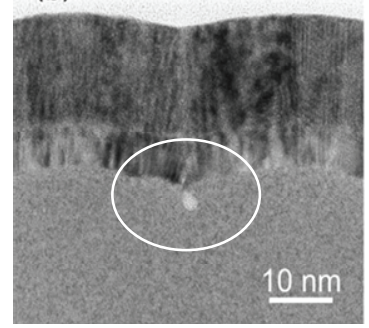

(c)

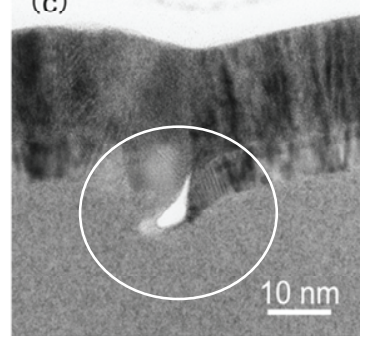

Fig. 5 Cross-sectional TEM images of magnetic recording media exposed to high humidity for $1 \mathrm{hr}$. (a) Wide coverage; (b),(c) enlarged views.

以上, ディスクを水蒸気雾囲気に曝した場合, 磁性層 や下地の NiP 層の腐食が磁性層の粒界より進行し, 下 層の NiP膜が大きく侵食されていく様子が断面観察によ り確認できた. 次に, これらの侵食する様子を各元素の 溶出挙動から追ってみた.

\section{3 媒体からの元素溶出挙動}

Fig. 6 (a)〜(c)は, Drop 法において $3 \%$ 硝酸液滴中に溶出 してくる $\mathrm{Co}, \mathrm{Cr}$ 及び $\mathrm{Ni}$ 濃度の経時変化を示す.これらの 図から, 各元素の溶出挙動を以下にまとめた.

Co：DLC 膜厚に対する溶出量を比較すると, $2 \mathrm{~nm}$ に おいて多量の Co が溶出することがわかる. Ni 量と比較す ると $2 \mathrm{~nm}$ のディスクだけ Co の溶出量の方が多くなってい た. $4.5 \mathrm{~nm}$ では溶出量は $2 \mathrm{~nm}$ の約 $1 / 100$ に減少し, 保護 膜としての DLC 膜の役割を果たしており, $7 \mathrm{~nm}$ 以上では 被覆性がさらに向上していることがわかる. 経時的な変 
化については, 被覆性が保たれる $7 \mathrm{~nm}$ 以上の膜厚では, 時間が経過してもほぼ同じ溶出量であることがわかった。 これは, 磁性層の腐食はある一定以上は進まないことを 意味していると考える.

$\mathrm{Cr}$ ：膜厚に対する溶出量については, Co と同様に DLC 膜厚が $2 \mathrm{~nm}$ の試料で溶出量が多いが, 4.5 及び $7 \mathrm{~nm}$ では $1 / 10$ に減少し, $10 \mathrm{~nm}$ 以上の膜厚ではさらに抑えら れていることがわかった. 経時変化については, Co の溶 出挙動は 60 分以降ではほとんど変化がみられないが, $\mathrm{Cr}$ 量は溶出時間に対して増加傾向にあることがわかる. これは, CoCr 系磁性膜の粒界における Cr 偏析層の存在 14),15)や，下地層に Cr 系合金層があることから，そこからの 溶出が加わるためと考える.

$\mathrm{Ni}$ : 膜厚に対する $\mathrm{Ni}$ 溶出量については, DLC 膜厚 2 $\mathrm{nm}$ で多いが, $4.5 \mathrm{~nm}$ より厚くなると溶出時間 120 分で $1 / 2$ 以下の溶出量となった. 経時的な変化については, 60 分を超えると溶出の速度が大きくなり, この時点を境に $\mathrm{NiP}$ 膜を侵食する速度が速くなっている. NiP 層は磁性 層より下層にあるため, 初期の段階では上層にある DLC 膜や磁性膜により腐食が抑えられたためと考える.

以上の結果より, 全体的な各元素の溶出挙動としては, 3 元素とも DLC膜厚 $10 \mathrm{~nm}$ 以上では膜厚依存がみられな いことがわかった. また, このように $10 \mathrm{~nm}$ 以上の厚い膜で も溶出が起こっているため, DLC 膜中にはある一定量の 欠陥が存在することが推測できる.一方, $7 \mathrm{~nm}$ 以下にお いては, 膜厚と Co の溶出量で良好な相関関係が得られ るため, DLC 膜の開発をする際に被覆性をあらわす指 標として有用であると考える. 例えば, 新しい成膜条件で 膜厚を設定する際, Co 溶出量を測定することで, 被覆性 の良否が判断可能となる.

さらに, $4.5 \mathrm{~nm}$ の試料においては, 初期段階の溶出挙 動をみるため, 30 秒, $1,3,5,20,30,40,60,120$ 分と細 かく溶出を行い, 各元素量を測定した.Fig. 7(a)に5 分ま でと(b)に 120 分までの溶出挙動を示す. 各元素における 初期段階の溶出挙動を調査することは, 腐食の経過を 知る上で有用な結果となった. Co の溶出は, 30 秒で 60 分に溶出される量の $1 / 4$ が出ていることから, 液滴を滴下 するとすぐに溶出が起こっている. Co の溶出は 40 分以 上で横這い状態となった. Cr は, 5 分までの溶出量は Co 量に対して約 1/10 となり, 磁性層の $\mathrm{CoCr}$ 比 $(\mathrm{Co}: \mathrm{Cr}=3$ : 1) と比較すると非常に少ない溶出量であった. その後少 しずつ直線的に増加し, 30 分くらいで磁性層の組成值 に近づき, 80 分あたりで Co 量より多くなった.一方, $\mathrm{Ni}$ は接液後 1 分まで溶出は見られず, その後 2 分ほどで Co 溶出量を越え, それ以降非常に速い速度で増加する 傾向となった.これは, Fig. 4 や Fig. 5 の断面写真にもある ように, NiP層は磁性層よりも腐食されやすく, 選択的に
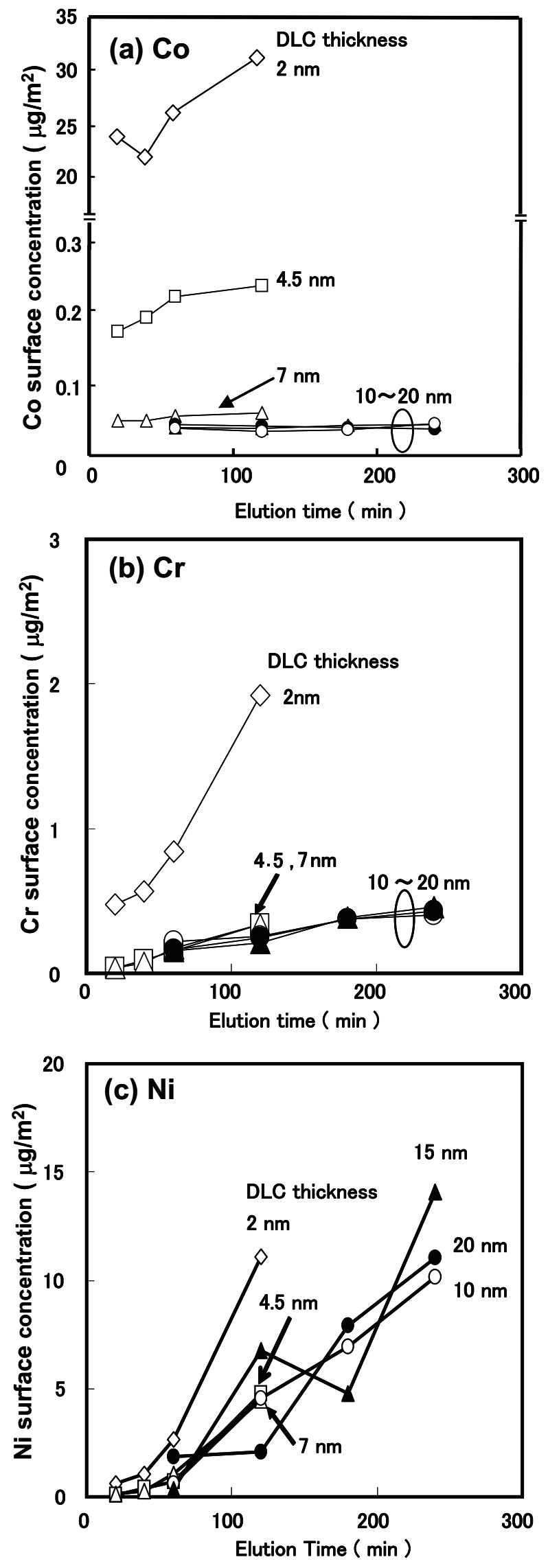

Fig. 6 Effect of DLC film thickness on elution behavior of (a) $\mathrm{Co}$, (b) $\mathrm{Cr}$, and (c) $\mathrm{Ni}$. 

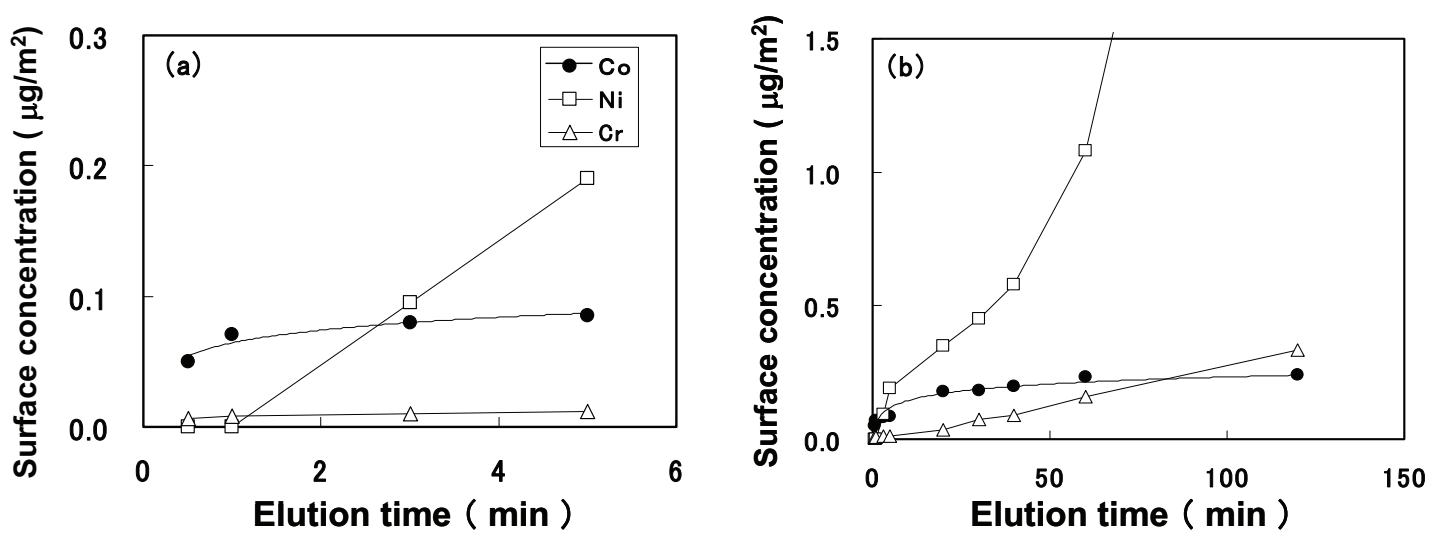

Fig. 7 Effect of elution time on elution of Co, Cr and Ni. (a) Up to $5 \mathrm{~min}$; (b) up to $120 \mathrm{~min}$.

侵食が進むことを明確にあらわしている。

Fig. 6 及び Fig. 7 の溶出挙動と Fig. 4 及び Fig. 5 の断面 TEM 観察をもとに考えた, 水蒸気によるディスクの腐食 進行モデルを Fig. 8(a)〜(c)に示す. 初期の(a)では, DLC 膜の被覆性不良部かつテクスチャーによる傷が深く入る ことによりできた磁性層の凹部より電池反応により磁性層 の Coと Crが溶出する. Fig. 5の断面写真では、磁性層の 柱状結晶に沿った侵食がみられるため、結晶粒界から 溶出が起きていると考えられる. 次に(b)では, Niの溶出が 始まり, NiP層の腐食が進行していくとともに, 磁性層から の $\mathrm{Co}$ 溶出は減速し, 40 分あたりから増加はみられない. Fig. 3 で腐食部の数が 5 時間と 100 時間で変化しなか ったことを考慮すると,この段階で DLC 膜の被覆性不良
箇所数は決定されると考える。一方で $\mathrm{Cr}$ は徐々に増加し, 30 分付近で磁性層の組成より多くなることから，この時 点で磁性層の溶解は抑えられ, 粒界に偏析している $\mathrm{Cr}$ 層や Cr 下地層からの溶出が起こっていると考える. (c)で は, Ni の溶出量は非常に速い速度で増加し, Co 溶出量 は一定となり, $\mathrm{Cr}$ 溶出量は増加し続けた結果, Coより多 くなる.これは, Fig. 3 にみられたように時間が経つと腐食 部の数が増加するといらよりも, 形状が大きくなっていく様 子から，限られた腐食部において CoCr 結晶粒界が徐々 に侵食されながら, NiP 層の速い腐食が進んでいくと推 定できる。

このように, SEM や TEM による観察結果と溶出法によ る各元素溶出挙動を合わせることにより, 腐食モデルが
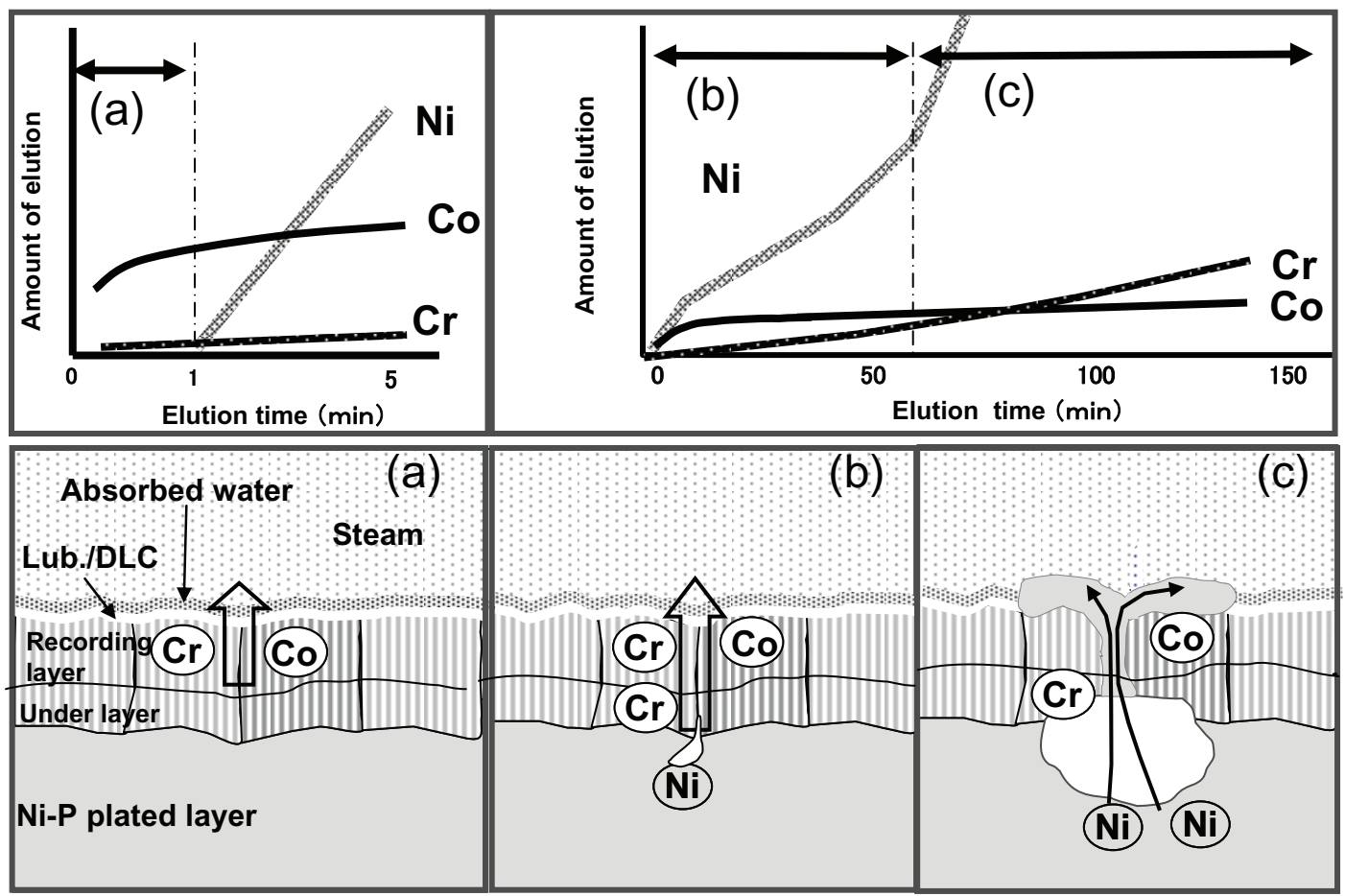

Fig.8 Proposed corrosion mechanism of magnetic recording media exposed to high humidity. 
構築できた. Drop 法では, ディスクに直接液滴を接触さ せる溶出方法を行っているが, 水蒸気中での放置状態 においては, Novotny らの報告にあるように, 高湿度環 境下ではディスク表面の吸着水が腐食を引き起こすため, 同様の現象でディスクの侵食が起こると考える.

本報においては，1種類のディスク構成について腐食 のモデル化を行ったが, 本実験で使用した溶出試験方 法は, 他の構成のディスクに対しても, 高湿度環境下に おける腐食を考察する上で有用な手段である.また，今 後はHDDの高記録密度化のために保護膜や基板およ び磁性層の膜構成などが大きく変わることや, 而環境性 の重要度も上がることから, 次世代機種に対しても活用 可能な評価方法であると考える.

\section{4. 結論}

高湿度環境下における磁気ディスクの腐食は, 断面 観察により, DLC 膜の被覆性不良箇所でありテクスチャ 一による傷が深く入ることによりできた磁性層のくぼみ部 分から起こることがわかった，その後は， CoCr 結晶粒界 が徐々に侵食されながら, NiP層の腐食が選択的に進ん でいく様子が観察できた。また, 腐食過程の観察に加え, $\mathrm{Co}, \mathrm{Cr}$ 及び $\mathrm{Ni}$ の溶出挙動を定量的に評価することで, 腐食のメカニズムを明らかにし, 水蒸気による腐食進行 モデルを提案することができた。

\section{References}

1) G. L Mcintire, and C. F. Brucker : IEEE Trans. Magn. 24, 5, 2221 (1988).

2) N. Harada, N. Honda, and K. Ouchi :Singakugihou (in Japanese), MR2000-25, 21 (2000).

3) V. Brusic, M. Russak, R. Schad, G. Frankel, A. Selius, and D. DiMilia : J. Electrochem. Soc., 136, 42 (1989).

4) B. Balakrisnan, B. Tomicik, and D. J. Blackwood : J. Electrochem. Soc., 149, B84 (2002).

5) S. Jung, and T. M. Devine : J. Electrochem. Soc., 151, B195 (2004).

6) Y. Ishikawa : Materia (in Japanese), 34, 11 (1995).

7) V. Novotny, G. Itnyre, A. Homola, and L. Franco : IEEE Trans. Magn., MAG-23, 3645 (1987).

8) Y. Onishi, H. Matsumura, T. Hase, H. Hayashi, M. Sato, and K. Katsumoto :IEEE Trans. Magn., 25, 3887 (1989).

9) E. T. Kuan, D. W.Park, J. Melo, D. Spaulding, J. J. Liu, and K. K. Kim :IEEE Trans. Magn., 40, 3195 (2004).

10) K. Tagami : IEEE Trans. Magn., MAG-21, 1435 (1985).

11) R. Ji, T. Liew, T. C. Chong : IEEE Trans. Magn., MAG-40, 3192 (2004).

12) A. Mizutani, H. Fukuda, Y. Yamaguchi, Y. Goto, and T. Yamamoto :Proc. 63th Bunsekikagaku-toronkai (in Japanese), Himeji, 2002.

13) A. Mizutani, Y. Goto, N. Nakamura, H. Chiba, and K. Watanabe : FUJITSU Sci. Tech. J., 42, 1, 113 (2006).

14) Y. Maeda, M. Takahashi : J. Apply. Phys., 68, 4751 (1990). 15) H. Hoffmann : IEEE Trans. Magn., MAG-22, 472 (1986).

2009年4月22日受理, 2009年7月16日採録 